\title{
Jasnogórskie piśmiennictwo dewocyjne w XVII-XVIII wieku. Recepcja modlitewnika Ksawerego Augustyna Rottera Ucieczka grzeszników albo nabożny zasmuconych rekurs do dzielney cudami Czestochowskiey Matki
}

Streszczenie. Jasnogórskie piśmiennictwo dewocyjne nierozerwalnie związane jest z Jasną Górą jako ośrodkiem kultu cudownego obrazu. Już od XVII wieku Jasna Góra obok ośrodka religijnego i duszpasterskiego stanowiła również prężny ośrodek kultury piśmiennej, oddziałującej na społeczeństwo przez dewocyjną książkę użytkową. Charakter tych książek podyktowany był przede wszystkim szczególnymi potrzebami Jasnej Góry jako ośrodka pielgrzymkowego. Jasna Góra, ze swym łaskami słynącym obrazem, była celem licznych pielgrzymek nie tylko z całego państwa polskiego, ale także ze Śląska, Moraw i Węgier. Paulini wobec masowego ruchu pątniczego nie pozostawali bierni. Docierali do pątników przez słowo drukowane w formie modlitewników, które popularyzowały również treści literackie. Życie Jasnej Góry jako miejsca świętego, największego ośrodka pielgrzymkowego w Polsce, znalazło odbicie w piśmiennictwie jasnogórskim XVII-XVIII wieku.

SŁowA KLuczowe: piśmiennictwo jasnogórskie, użytkowa książka dewocyjna, Ksawery Rotter, Jasna Góra, pisarze paulińscy, modlitewniki.

Dewocyjne piśmiennictwo jasnogórskie już w początkach XV stulecia utrwalone zostało w rękopisach, a sto lat później przybrało nowy kształt formę druku ${ }^{1}$. Nieliczne w XVI stuleciu druki były ściśle związane z dusz-

\footnotetext{
${ }^{1}$ Zob. J. Zbudniewek, Kopiarze dokumentów Zakonu Paulinów w Polsce do końca XVII wieku, „Archiwa, Biblioteki i Muzea Kościelne” 34, 1977, s. 311 i n.; idem, Kodeks Regut
} 
pasterską posługą $\mathrm{w}$ jasnogórskim sanktuarium. Wraz z rozwojem ruchu pielgrzymkowego na Jasną Górę, szczególnie w drugiej połowie XVII wieku, książka dewocyjna, mająca charakter użytkowy, zaczęła wywierać coraz większy wpływ na religijną kulturę masową ${ }^{2}$.

Żywotność książki religijnej była nierozerwalnie związana z aktualnością jej treści, która nie wygasła nawet po wielu latach, o czym świadczą nowe wydania starych dzieł. Teksty wydawane i powielane na użytek jasnogórskich pątników - częstochowskie modlitewniki, śpiewniki czy przewodniki - integrowały całe pokolenia we wspólnych postawach kultowych oraz utrwalały i rozpowszechniały historię jasnogórskiego locus sacer.

Rozwój jasnogórskiego piśmiennictwa dewocyjnego w XVII-XVIII wieku można rozpatrywać jedynie w odniesieniu do druków, które zachowały się do czasów obecnych. Pełny obraz produkcji i kolportażu użytkowej książki religijnej jest niemożliwy, ponieważ zachowane druki stanowią tylko nieznaczną część piśmiennictwa autorstwa głównie pisarzy paulińskich. Poza tym dewocyjna książka użytkowa rzadko bywała uwzględniana w zachowanych inwentarzach bibliotek szlacheckich, mieszczańskich i plebańskich, co nie oznacza jednak, że nie była obecna w tych środowiskach. Aktywność pisarska paulinów znajduje potwierdzenie w danych źródłowych, dokumentujących funkcjonowanie założonej w 1693 roku drukarni na Jasnej Górze ${ }^{3}$.

O ile pierwsze dzieła paulinów: Mikołaja z Wilkowiecka, Kaspra Biedrzychowskiego, Paulina Benedykta Kłodawskiego, Andrzeja Gołdonowskiego, Ambrożego Nieszporkowicza i Sebastiana Stawickiego, drukowane w Krakowie, Rzymie, Wrocławiu, Toruniu, Gdańsku, Wilnie oraz Jarosławiu były wydawane $\mathrm{w}$ niewielkich nakładach, o tyle powstanie drukarni jasnogórskiej było istotnym wkładem paulinów w rozwój polskiej religijnej książki użytkowej, stworzyło bowiem nowe możliwości edytorskie - $\mathrm{w}$ dodatku - na miejscu.

Drukarnię jasnogórską zaczęto organizować w 1692 roku, a szczególne zaangażowanie w jej tworzeniu przejawiał ówczesny prowincjał paulinów polskich o. Mikołaj Szotarewicz. Czcionki i materiały zakupiono we Wrocławiu i już w 1693 roku wydano trzy pierwsze książki.

Paulińskich zwany "Katenatem” na tle kultury ksiązki w Zakonie Paulinów w XVI stuleciu, w: Ksiażka rękopiśmienna XV-XVIII w., Warszawa 1980, s. 107 i n.

${ }^{2} \mathrm{H}$. Żerek, Katolicka kultura religijna społeczeństwa polskiego w czasach saskich w świetle piśmiennictwa dewocyjnego, Łódź 1982, s. 17 i n.; J. Topolski, Problemy metodologiczne korzystania ze źródeł literackich w badaniu historycznym, w: Dzieło literackie jako źródło historyczne, red. Z. Stefanowska, J. Sławiński, Warszawa 1978, s. 18 i n.

${ }^{3}$ Por. H. Czerwień, Drukarnia oo. paulinów w Częstochowie w latach 1693-1729, Lublin 1966. 
W XVIII wieku drukarnia paulińska na Jasnej Górze należała do warsztatów średniej wielkości i była w stanie sprostać wydawaniu nawet poważnych pozycji, wymagających dużego zasobu czcionek.

Jasnogórski ośrodek wydawniczy miał ściśle określony profil. Celem drukarni było dostarczenie taniej książki jak największej liczbie odbiorców. Była to książka głównie religijna, ponieważ takiej poszukiwali pielgrzymi przybywający na Jasną Górę. Pozycje świeckie stanowiły z konieczności margines prac drukarni. W pierwszych latach swego istnienia oficyna paulińska miała dość urozmaicony asortyment wydawnictw. Drukowano podręczniki teologiczne, kazania, literaturę ascetyczną, dzieła dotyczące historii klasztoru i dziejów obrazu Matki Bożej Jasnogórskiej, literaturę polityczna, prawna, popularne poradniki medyczne, hagiografię, modlitewniki, zbiory pieśni. Poczesne miejsce znalazła również poezja. Na skutek szczególnego popytu i zapotrzebowania drukowano jednak prawie wyłącznie modlitewniki, literaturę ascetyczną, zbiory pieśni i elementarze dla szkół elementarnych.

W latach 1693-1863 wydano na Jasnej Górze z dotychczas znanych - pomijając druki akcydensowe, luźno wydawane pieśni i obrazki religijne 1180 pozycji w 10279 arkuszach drukarskich. Z tego w języku łacińskim 2005,5 arkusza, w języku polskim 8280,5 oraz 6 arkuszy w języku czeskim. W języku łacińskim wydawano raczej pozycje drobne lub podręczniki teologiczne, zbiory prawa zakonnego oraz księgi liturgiczne. Porównując liczbę wydanych na Jasnej Górze arkuszy, wyraźnie zauważalna jest preferencja wydawnictw $w$ języku polskim w proporcji 1:54

Specyfika druków jasnogórskich stanowi utrudnienie w określeniu mocy produkcyjnej jasnogórskiej drukarni. Zarówno zestawienie tytułów, sporządzone przez Józefa Siennickiego, jak i Bibliografia polska Karola Estreichera wykazują w tym względzie wiele braków. Dotyczą one przede wszystkim druków drobnych, jedno- lub dwuarkuszowych, okolicznościowych mów i panegiryków, tez dysput, tekstów pieśni, kolejnych wydań modlitewników, katalogów zakonnych, rubryceli, druków przeznaczonych do użytku wewnętrznego zakonu, jak np. listów pasterskich. Siennicki w swoim zestawieniu wydawnictw jasnogórskich pominął Elementarz polski, wydany w pierwszej połowie XIX wieku. Estreicher natomiast odnotował tylko jedno jego wydanie, podczas gdy zachowane rachunki drukarni świadczą o tym, iż Elementarz został wydany na Jasnej Górze 30 razy w łącznym nakładzie 239 tysięcy egzemplarzy ${ }^{5}$.

\footnotetext{
${ }^{4}$ Por. H. Czerwień, Drukarnia paulinów w Częstochowie w latach 1730-1863, Bytom 1998.

${ }^{5}$ H. Czerwień, Drukarnia oo. paulinów, s. 84 i n.
} 
Posługa paulinów względem wzrastającej liczby pątników przybywających na Jasną Górę podyktowała charakter ich twórczości pisarskiej, szczególnie kaznodziejskiej i dewocyjnej. Treść jasnogórskich druków odnosiła się w sposób bezpośredni do szerokiego kręgu odbiorców. W oficynie jasnogórskiej tłoczono nie tylko dzieła o tematyce teologicznej, dogmatycznej i moralnej, ale także - zarówno w wersji polskiej, jak i łacińskiej - praktyczne abecedariusze życia duchowego oraz poradniki dla spowiedników.

Jednym z pierwszych był Schema regulare seu sermones claustrales institutioni et exornationi spirituali religiosorum (Częstochoviae 1694) ${ }^{6}$, pióra Bartłomieja Pawła Szotarewicza. Dzieło stanowiło zbiór konferencji, dotyczących powołań zakonnych, ślubów, ćwiczeń duchownych i ascetycznych, modlitw, cnót, wad oraz eremityzmu zakonnika. Kolejne dwie prace to Pabulum animae christianae (Częstochoviae 1706) oraz Abecedarium vitae spiritualis explicans (Częstochoviae 1720) ${ }^{7}$ Jana Chryzostoma Adamowicza przeznaczone dla nowicjatu zakonu paulinów, a także Directorium spiritualis vitae FF. Eremitarum Ordinis S. Pauli Eremitae (Cracoviae 1649) autorstwa Grzegorza Tereckiego. Wspomnieć warto również Akademię Pobożności (1628) oraz Elementarzyk ćwiczenia duchownego (Kraków 1626), niezwykle cenne, pochodzące z XVII wieku prace dominikanina Mikołaja z Mościsk, które wznowiono w drukarni jasnogórskiej w 1722 roku.

Wspomniany już Grzegorz Terecki jest również autorem poradnika dla spowiedników Confessio et instructio idiotae (Cracoviae 1655), reprezentującego nurt piśmiennictwa, w którym wyrażano troskę o właściwą formację szafarzy sakramentu pokuty. Dzieło to ma dziś wyjątkową wartość historyczna, ukazuje problem spowiedzi dzieci oraz ludzi prostych, a także niepełnosprawnych fizycznie i umysłowo. Dotyka kwestii konwersji innowierców i ludzi opętanych nałogiem, jak również problematyki zabobonów i czarów. Paulińscy moraliści propagowali przestrzeganie zasad moralności w wydawanych w XVIII wieku dziełach, wśród których na szczególną uwagę zasługują Summarium theologiae moralis tripartitum (Częstochoviae 1795) oraz Breviarum universae theologiae moralis (Częstochoviae 1795) Bonawentury Meressa, jak również Theologia moralis Gaudentego (Częstochoviae 1798) Jakuba Walęckiego.

\footnotetext{
${ }^{6}$ Pod zmienionym tytułem Sermones claustrales institutioni et exornationi spirituali religiosorum immo quorumvis christianorum, Częstochoviae 1781.'

${ }^{7}$ Wydanie drugie pod zmienionym tytułem Abecedarium perfectionis religiosae, Częstochoviae 1720.

${ }^{8}$ Wydanie drugie Cracoviae 1686.
} 
Dzieła autorów paulińskich: Pafnucego Brzezińskiego ${ }^{9}$, Ignacego Gorzeńskiego ${ }^{10}$, Brunona Osieckiego ${ }^{11}$, Fortunata Opełczyńskiego ${ }^{12}$, Waleriana Szawelskiego ${ }^{13}$ oraz Teodora Grubera ${ }^{14}$, wydawane w klasztornej oficynie w formie kazań na niedziele i święta, na uroczystości maryjne oraz na poszczególne okresy roku liturgicznego, były podstawową lekturą dla jasnogórskich kaznodziejów. W okresie rozkwitu kaznodziejstwa paulińskiego w drugiej połowie XVIII wieku, oprócz wspomnianych obszernych zbiorów, wydawano również pojedyncze teksty kazań oraz okolicznościowych mów pogrzebowych i ślubnych ${ }^{15}$.

Jasnogórska literatura hagiograficzna nie tylko była wykorzystywana przez paulinów w ich duszpasterskiej posłudze słowa, ale także była dostępna dla szerszych kręgów czytelniczych. Po wspomnianych już pracach Andrzeja Gołdonowskiego ten typ pisarstwa reprezentowali: Bartłomiej Szotarewicz ${ }^{16}$, Dioznizy Chełstowski ${ }^{17}$ oraz Innocenty Pokorski ${ }^{18}$.

Piśmiennictwo jasnogórskie $\mathrm{w}$ omawianym okresie $\mathrm{w}$ znacznej większości poświęcone było kultowi maryjnemu oraz czci Matki Bożej Jasnogórskiej. Kazania i panegiryki, traktaty i poezje, wielokrotnie na nowo redagowane i wznawiane, podejmujące tę samą tematykę, stały się świadectwem zainteresowania Jasną Górą jako ośrodkiem kultu oraz społecznej akceptacji odnajdywanych tu wartości. Pisarstwo mariologów paulińskich, zwłaszcza Dionizego Łobżyńskiego ${ }^{19}$,

\footnotetext{
${ }^{9}$ Zbiór słowa Bożego y pochwat świętych Pańskich z pola kaznodziejskiego zgromadzony, Jasna Góra 1764.

${ }^{10}$ Nowy ogłos chwały świętych Boskich... to jest kazanie na wszystkie święta roczne, Jasna Góra 1717.

${ }^{11}$ Prymicje pracy kaznodziejskiej, Jasna Góra 1738.

${ }^{12}$ Kazania adwentowe... i postne, Jasna Góra 1796; Kazania święte i przygodne, cz. 1, Jasna Góra 1798.

${ }^{13}$ Zbiór przygodny kazań y przemów publicznieyszych, Jasna Góra 1782.

${ }^{14}$ Kazania na niektóre uroczystości świętych Pańskich, Jasna Góra 1776, wyd. 2, 1779; Kazania niedzielne, t. 1-3, Jasna Góra 1778; Kazania postne, Jasna Góra 1780; Kazania adwentowe, Jasna Góra 1781.

${ }^{15}$ Zob. S. Szafraniec, Konwent paulinów jasnogórskich 1382-1864, Rzym 1966, s. 47-65.

${ }^{16}$ Byssus et purpura seu vita et martirium d. Stanislai episcopi Cracoviensis, Częstochoviae 1693, wyd. 2, 1695.

${ }^{17}$ Kamień czeski w Koronie polskiej osadzony to jest Jadwiga święta, Częstochowa 1716; Colloquia charitativa s. Stanislai episcopi Cracoviensis, Częstochoviae 1713; Epitaphia Divi Martyris Stanislai Episcopi Cracoviensis, Częstochoviae 1713.

${ }^{18}$ Wzór doskonałości ś. Paweł I Pustelnik cudami za żywota i po śmierci w Kościele świętym wstawiony, Warszawa 1725.

${ }^{19}$ Dies natalis, Cracoviae 1650; Przenosiny triumphalne, Kraków 1644; Decas Litaniarum, wyd. 3, Częstochoviae 1693.
} 
Ambrożego Nieszporkowicza ${ }^{20}$ czy Anastazego Piotra Kiedrzyńskiego $^{21}$, przez kult Maryi Królowej Korony Polskiej w jasnogórskim obrazie w znacznej mierze przyczyniło się do rozwoju idei królewskości Maryi oraz zapoczątkowało rozwój teologii Jasnej Góry jako miejsca pielgrzymkowego.

Użytkową książkę dewocyjna, w postaci modlitewników i przewodników pątniczych, drukowano na Jasnej Górze przede wszystkim z myślą o pielgrzymach. Ponieważ środowiska czytelnicze, począwszy od drugiej połowy XVIII wieku, rozszerzały się o tę właśnie grupę odbiorców, wzrastało zainteresowanie tym rodzajem piśmiennictwa jasnogórskiego, które stało się zjawiskiem masowym ${ }^{22}$. Zbiory pieśni i modlitw oraz teksty nabożeństw maryjnych zawarte $\mathrm{w}$ pątniczych książeczkach nie były jedynie modlitewnikami wychodzącymi z jasnogórskiej drukarni, lecz także sprawnym narzędziem oddziaływania jasnogórskich paulinów na szerokie rzesze pątników.

Wraz ze wzrostem świadomości społecznej wśród przybywających na Jasną Górę pielgrzymów zmienił się także społeczny wymiar pisanych przez paulinów dzieł. Pisano i wydawano specjalne modlitewniki stanowe oraz zbiory modlitw, które miały upowszechniać poszczególne kulty oraz nabożeństwa, cieszące się w XVII i XVIII wieku szczególną popularnością. Wspomnieć warto poradnik przeznaczony dla chrześcijańskiego gospodarza, napisany przez o. Andrzeja Gołdonowskiego jako załącznik do żywotu św. Izydora Oracza ${ }^{23}$. Ten hiszpański święty, patron pracy fizycznej oraz propagator idei zapłaty w niebie za trudy pańszczyzny, był w XVII wieku niezwykle popularny wśród polskiej szlachty. Wśród kobiet popularnością cieszył się modlitewnik Heroina chrześcijańska (Częstochowa 1706) autorstwa paulina o. Rudolfa Pollacza. Te wielokrotnie wznawiane i stosowane jeszcze na początku XX wieku teksty zawierały bogaty repertuar nabożeństw dziennych, tygodniowych, miesięcznych, rocznych i okolicznościowych. Autor, będąc jednocześnie organizatorem jasnogórskiej drukarni, wydał też zredagowany przez siebie modlitewnik dla kapłanów Manuale pietatis (Częstochoviae 1694), pozostający w użyciu przez cały XVIII wiek.

Na Jasnej Górze wydawano także modlitewniki zachęcające do odprawiania nabożeństwa za dusze w czyśćcu, jak Zegar czyśćcowy czyli

${ }^{20}$ Odrobiny stołu królewskiego, Kraków 1683; Analecta mensae Reginalis, Cracoviae 1681; Officina emblematum, Cracoviae 1680.

${ }^{21}$ Mensa Nazarea, Częstochoviae 1763, wyd. 2, 1769.

${ }^{22}$ H. Żerek, op.cit., s. 93 i n.

${ }^{23}$ Krótkie zebranie świętobliwego żywota S. Izydora Rolnika, Kraków 1629. 
nabożeństwo codzienne za dusze w czyśćcu cierpiące z 1798 roku. Bractwo Aniołów Stróżów, działające w sanktuarium jasnogórskim od 1625 roku, propagowało kult Aniołów Stróżów, rozpowszechniając drukowane Koronki (Częstochowa 1722). Tak duża różnorodność modlitewników jasnogórskich podkreśla charakter jakże różnych potrzeb duchowych pielgrzymów przybywających do częstochowskiego sanktuarium. To właśnie z myślą o nich dwukrotnie wznowiono polską wersję łacińskiego przekładu dzieła Jana Drewsa Dystrakcje podróżnych pobożne (Częstochowa 1744 i 1751).

Wśród jasnogórskiego piśmiennictwa dewocyjnego szczególne miejsce zajmowały modlitewniki maryjne. Prezentowane $\mathrm{w}$ formie zbiorów zawierających modlitwy, psalmy, hymny, litanie oraz koronki do Najświętszej Maryi Panny, ułożone w kolejności dni tygodnia, jak w modlitewniku Tydzień Maryji albo Psatterz Imienia Nayświętszey Boga Rodzicy Panny, na tygodniowe nabożeństwo rozdzielony z 1760 roku, wydawane wraz z przewodnikiem pątniczym, stanowiły szczególny typ książeczki jasnogórskiej, znany z druków pochodzących jeszcze z pierwszej połowy XVII wieku, jak np.: Skarbnica kościoła Jasney Gory Czestochowskiego Andrzeja Żymicjusza (Kraków 1618) oraz Summariusz historiey o Obrazie Panny Mariey Andrzeja Gołdonowskiego (Kraków 1639).

Takim typem modlitewnika, a jednocześnie zbiorem przepisów, jak należy pielgrzymować na Jasną Górę i jakie modlitwy odmawiać w czasie pielgrzymowania, było dzieło o. Ksawerego Augustyna Rottera. Ten mały, w formacie małej ósemki, niepozorny modlitewnik, poświęcony czci Najświętszej Marii Panny w jasnogórskim obrazie, zatytułowany pierwotnie Refugium peccatorum seu devotus afflictorum recurses ad Thaumaturgam Częstochoviensem Matrem i wydany w 1749 roku, tłumaczony był na wiele języków, w tym również na język polski, pod tytułem Ucieczka grzeszników albo nabożny zasmuconych rekurs do dzielney cudami Częstochowskiey Matki (wydany po raz pierwszy w drukarni jasnogórskiej w 1756 roku), oraz na język czeski i niemiecki, a tym samym udostępniony pielgrzymom spoza granic Polski ${ }^{24}$.

Modlitewnik nawiązuje do modnych wówczas książek do nabożeństwa, których początek w warunkach jasnogórskich zakreślił Stanisław Zakrzewski w tekście zatytułowanym Droga częstochowska. Wydany

\footnotetext{
${ }^{24}$ Wersja łacińska: Vratislaviae 1749, wyd. 2, 1767; tłumaczenia niemieckie: Zuflucht der Sünder oder andächtiger Zutritt der Betrübten zu der im Czenstochauer Gnaden - Bild, Breslau 1749 i później wielokrotnie wydawana ze sztychem Strachowskiego; przekład czeski: Utečka hrešnikov aneb horanca nabožnost do Naysvetiessy Panni Maryi na Jasnej Hore, Częstochowa 1800.
} 
w 1623 roku, objaśnia szlak pielgrzymi, sposób odbywania pielgrzymki i sposób zachowania się na Jasnej Górze po dotarciu do klasztoru. Współczesna mu literatura, szczególnie ta, która wyszła spod pióra wspomnianego już o. Andrzeja Gołdonowskiego, przybliżyła kontakt wiernych z obrazem, prowokując do odmawiania odpowiednich modlitw i zawierzenia się Najświętszej Matce, aż po bezwzględną wiarę w cud ${ }^{25}$. Późniejsza literatura, od drugiej połowy XVII wieku, zrodzona wraz ze wzrostem ruchu pielgrzymkowego na Jasną Górę, została podyktowana potrzebami wzrastającej pobożności maryjnej, z wyraźnym zaakcentowaniem jej użytkowego charakteru, kształtującego religijną kulturę masową.

Teksty drukowane na użytek pątników jasnogórskich w modlitewnikach, przewodnikach i śpiewnikach integrowały całe pokolenia we wspólnych postawach kultowych. Również powielanie druków poświęconych dziejom cudownego obrazu przyczyniało się do utrwalania i upowszechniania w kolejnych generacjach zapisów historycznych i legend, dotyczących zarówno samego wizerunku, jak i jasnogórskiego świętego miejsca. Słowu pisanemu towarzyszyły kazania, także nierzadko drukowane, w których wielu kaznodziejów nie tylko dawało popis krasomówstwa, ale też kreowało nowe teksty modlitewne, których ilustracją jest właśnie dzieło o. Rottera.

Pomysł napisania tego dzieła zrodził się z potrzeby serca jednego z najżarliwszych czcicieli jasnogórskiego obrazu. Ucieczka grzeszników powstała pod wpływem studiów nad historią obrazu i jego oddziaływania na wiernych. Poza generalnym stwierdzeniem faktu istnienia cudownego wizerunku autor utrzymał utwór w tonacji dziękczynnej modlitwy za obecność obrazu i możliwość wędrowania do niego, bycia przy nim i pozostawania z nim w relacji duchowej.

O. Rotter wydał Ucieczkę grzeszników wyłącznie z myślą o pielgrzymach, narzucił jej formę modlitewna, pomocną w głębszym przeżywaniu pobytu w klasztorze, spowiedzi i radosnego powrotu do domu z sugestią, aby nieść w świat cudowny wizerunek Najświętszej Panny. Dzieło to można nazwać poradnikiem duchowym, nawiązującym do wcześniej wspomnianego traktatu o. Gołdonowskiego dla "chrześcijańskiego gospodarza” (na przykładzie św. Izydora Oracza) lub do formy modlitewnika dla kobiet Heroina Chrześcijańska o. Rudolfa Pollacza.

Pierwsze wydanie Ucieczki grzeszników w wersji łacińskiej ukazało się we Wrocławiu w 1749 roku. Tekst formatu małej ósemki liczył 72 strony

${ }^{25}$ S. Zakrzewski, W kręgu kultu maryjnego. Jasna Góra w kulturze staropolskiej, Częstochowa 1995, s. 131 i n. 
i wraz z małą ryciną dedykowany był Franciszkowi Wojciechowi Paczyńskiemu, księciu na Tenczynie ${ }^{26}$, który był jednocześnie jego sponsorem²7. Później ukazały się dalsze wznowienia. Niemiecką wersję modlitewnika wydano we Wrocławiu w latach 1749, 1756 i 1770. Po drugim wydaniu łacińskim ukazało się wydanie w języku polskim, wytłoczone na Jasnej Górze w 1756 roku. Około 1766 roku w oficynie akademickiej we Wrocławiu wytłoczono po raz ostatni 3000 egzemplarzy Refugium peccatorum ${ }^{28}$, a w 1781 roku - 10000 egzemplarzy polskiej wersji Ucieczki grzeszników. Wszystkie następne edycje polskiej wersji, a więc w latach 1811, 1824, 1830, 1835, 1841, 1844 i 1854, zostały wydrukowane według układu z 1781 roku, w dużej ósemce i w objętości 96 stron $^{29}$. Dla pątników z Moraw pielgrzymujących w tym czasie do sławnej Częstochowy książkę przetłumaczono na język czeski i w 1800 roku wytłoczono ją w miejscowej klasztornej drukarni ${ }^{30}$.

Przed przystąieniem do analizy tego modlitewnika warto zauważyć, że osobnym elementem w poszczególnych edycjach były zdobienia. W zasadzie wszystkie zawierają wizerunek Matki Boskiej Jasnogórskiej. W drukach współczesnych autorowi posługiwano się tłokami dostępnymi w oficynie jasnogórskiej, które w miarę używania uległy zamazaniu, toteż ostatnie druki Ucieczki grzeszników są już zupełnie nieczytelne ${ }^{31}$.

${ }^{26}$ Hrabia na Tenczynie Franciszek Adalbert (Wojciech) h. Topór to niewątpliwie syn Adalberta Paczyńskiego, który w połowie XVII wieku był notariuszem księstw opolskiego i raciborskiego, zmarł w 1706 roku (Visitationsberichte der Diözese Breslau, wyd. J. Jungnitz, s. 78 i n). Franciszek Adalbert w 1732 roku kupił dobra Szymiszów koło Strzelec Opolskich. Zmarł w 1736 roku w Szymiszowie. J. Król, Dzieje parafii Szymiszów, Opole 1995, s. 16, 375. Miejscowości wymienione w dedykacji to: Bycina parafia Byczyna, Chechło, Taciszów koło Gliwic, Zdzieszowice, Rozmierka, Szymiszów koło Strzelec Opolskich, Krowiarki i Maków koło Raciborza. Informacje powyższe zawdzięczam ks. infułatowi prof. dr. hab. Kazimierzowi Doli, któremu składam w tym miejscu szczególne podziękowania.

${ }^{27}$ Por. A. Mendykowa, Ksiażka polska we Wrocławiu w XVIII w., Wrocław 1975, s. 95 i n.

${ }^{28}$ Archiwum na Jasnej Górze (dalej: AJG) 250, s. 43.

${ }^{29}$ AJG 245, s. 493; por. J. Zbudniewek, Rotter Franciszek Ksawery Augustyn, w: Słownik polskich teologów katolickich, t. 3, s. 512-513; K. Estreicher, Bibliografia polska, t. 26, Kraków 1915, s. 391.

${ }^{30}$ Utecka hresnikuw aneb horauca naboznost do Neyswetiegssy Panni Maryi na Jasnej Hore..., Częstochowa 1800, ss. 96 i ryc. Opisuje ją S.J. Brandtkie, Wiadomości o języku polskim w Szląsku i o polskich Szlazakach, „Mrówka Poznańska” 2, 1821, t. 1, s. 235. Pisze, że w 1802 roku widział mnóstwo tych książek w języku czeskim, wystawionych na sprzedaż w kramikach w Nowej Częstochowie. Do obecnej pracy nie udało się odnaleźć choćby jednego egzemplarza.

${ }^{31}$ AJG 572, s. 15. 


\section{UCIECZKA \\ Grzerznikow}

Albo

Nabożny záfmuconych

R E K U R S

Do dźielney cudámi Częftochowikiey

$M$ A $T$ K I.

Tam itus

Od lat trzech fer fiedmiudźiefiąt

y czterech nieporownane lafk

fwoich Aárby dla wiernych

S LA FUI A C EY.

dla więkfzego wfzyltkim do Tey nabożnym Mátki, ile prawdźiwego zbáwienia pofrlku, z Łácinikiego, ná Polfki ięzyk:

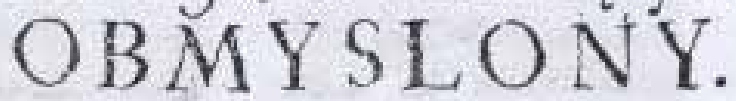

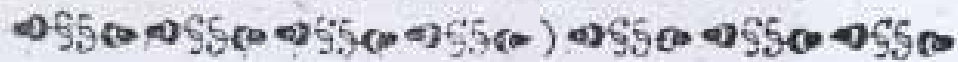

Roku Panfkiego $175^{6}$.

W Drukárni Jifney Gory Czẹitochowfkiey. 
Ucieczka grzeszników zawiera modlitwy do Matki Bożej Jasnogórskiej, której, jak czytamy we wstępie, cudowny wizerunek znajduje się na Jasnej Górze od 374 lat i obdarza wiernych niezrównanymi łaskami. Dzieło napisane zostało "ku większemu wszystkich pożytkowi, a nade wszystko dla zbawienia”32. Rozpoczyna je inwokacja do „Sługi Maryi”, w której autor tłumaczy, ,jak ma pożytku cudownego obrazu nawiedzać...", ale nie tylko wtedy, gdy „w samej osobie dla złożenia pokłonu Maryi na Święte Jej miejsce do Częstochowy wybierasz się, ale codziennie w domu przed Św. Tejże obrazem, potrzebnie zażywać Jej możesz; bo wiesz, że Marya na każdym miejscu łaskawe daie ucho dla sług swoich, aby ich słuchała i wysłuchała".

W pierwszej modlitwie Rotter nie przedstawia dziejów obrazu, cudów i łask, z jakich słynie, ale z pokorą klęka przed nim i prosi: „niechaj na posiłek wątlejącego we mnie ducha spadną z tego najobfitszego dobroci Boskiego stołu dostateczne łask Twoich drobiny..." ${ }^{33}$.

Po tym wezwaniu autor sugeruje, że Karol Wielki chciał święty obraz przenieść do Akwizgranu, ale ponieważ ten wątek nie jest mu potrzebny, więc go urywa, w zamian za to czyni aluzję do miejsca, w którym obraz został umieszczony na stałe. Wspomina (błędnie!) księcia Leona, który sprowadził obraz do Polski, oraz pustelników, z którymi Matka Najświętsza w cudownym obrazie „zamieszkuje”. W modlitewnej wizji odnosi się do walk na Rusi i zamku bełskiego, skąd obraz „oświecał cała, pozostającą jeszcze bez prawdziwej wiary Ruś" ${ }^{\prime 34}$.

Fakty historyczne przeplatane są osobistymi refleksjami autora, po których prosi „Rodzicielkę wiecznego światła” o oświecenie swojego serca i oczyszczenie go ze zgubnych nałogów, a także o wskazanie drogi do zbawienia, które wyrażać się będzie wiecznym oglądaniem „słońca sprawiedliwości", czyli Jezusa Chrystusa.

Podjęcie kolejnego wątku historycznego jest próbą udzielenia odpowiedzi na pytanie, dlaczego „najłaskawsza Matka” wybrała właśnie Ruś, zamieszkałą przez Tatarów i pogan, na swoją siedzibę. Odpowiadając na to retoryczne pytanie, autor przywołuje obraz oblężenia zamku w Bełzie przez wojsko tatarskie, podczas którego "nikt nie odnosi takiej krzywdy jak Maryja”35. Nieprzyjacielska strzała „rani” szyję Matki Bożej w cudownym wizerunku. Autor określa tę zbrodnię jako najobrzydliwszą niegodziwość, której nawet

\footnotetext{
${ }^{32} \mathrm{~K}$. Rotter, Ucieczka grzeszników albo nabożny zasmuconych rekurs do dzielney cudami Częstochowskiey Matki, Częstochowa 1756, s. A1.

${ }^{33}$ Ibidem, s. A2.

${ }^{34}$ Ibidem, s. A5.

${ }^{35}$ Ibidem, s. A6.
} 
krwawe łzy nie są w stanie odpokutować. Niebo jednak mści się za krzywdę wyrządzoną swojej Królowej. Aniołowie zwyciężają nieprzyjacielskie wojska. Książę Władysław Opolczyk, za przyczyną Najświętszej Maryi Panny, odnosi zwycięstwo nad oblegającymi Bełz wojskami tatarskimi i litewskimi. Po tym, jak strzała wypuszczona przez Tatara rani obraz, mgła otacza oblegających i strach ich ogarnia, a książę, wykorzystując okazję, uderza z wojskiem na nieprzyjaciół i gromi ich. I tu z ust autora wydobywa się zawołanie: „O dobra Matko zachowaj mnie od podobnego występku”36. Tymi słowami autor prosi, aby Matka w łaskawości swojej zachowała go od popełnienia grzechu śmiertelnego, za który na sądzie Bożym otrzymałby wyrok śmierci wiecznej i zostałby skazany na wieczne potępienie w piekle.

Na kanwie dziejów cudownego wizerunku o. Rotter dostrzega księcia Władysława Opolczyka, obrońcę zamku bełskiego, który w trosce o bezpieczeństwo obrazu postanawia przewieźć go do swojego księstwa na Śląsku. Jednakże wyrokiem opatrzności Boskiej na siedzibę cudownego obrazu wybrano nie opolski zamek otoczony wodami, lecz inne miejsce, zewsząd widoczne częstochowskie wzgórze, gdzie Matka w cudownym wizerunku „zamieszkała” wraz z zakonnikami św. Pawła Pustelnika. Zwracając się do Niej słowami „Gwiazdo wyiskrzona, Gwiazdo poranna", autor prosi ponownie o oświecenie zaćmionych nałogami serc ludzkich, o uwolnienie ich od ciemności grzechu.

Po 48 latach husyci, zwabieni rozgłosem i licznymi wotami, napadli na klasztor i wywieźli obraz pod obecny kościół św. Barbary w Częstochowie, gdzie jeden $z$ napastników rzucił w gniewie obraz na ziemię i rozbił go na trzy części, a inny uderzył dwukrotnie szablą w prawy policzek Maryi i uczynił na nim dwie szramy. Siłą Boskiej ingerencji w miejscu obrazoburstwa wytrysnęło źródło, gdzie „łaski chorób uleczania na wieczną tego przypadku pamiątkę zostawiła" 37 .

W zasadniczej części modlitewnika autor wspomina cudowne uzdrowienia chorych, ale ich nie wylicza, sugerując, że Matka Boża „samą nawet duszę z ciała wygnaną na powrót oddaje”, ponieważ jest Matką Życia. Wspomina ludzi umysłowo chorych, którym Maryja „pomieszane zmysły do pory przywraca doskonałej”, gdyż jest prawdziwą Mądrości Stolicą. W dalszej kolejności wymienia cierpiących na apopleksję i sparaliżowanych, których Ona „podźwiga miłosiernie”, gdyż jest Matką Miłosierdzia. Konkluduje, że „wiele jest jeszcze ludzkich cierpień i dolegliwości, wszystkie jednakże zostają cudownie uleczone przed świętym Obrazem"38.

\footnotetext{
${ }^{36}$ Ibidem.

${ }^{37}$ Ibidem, s. B1.

${ }^{38}$ Ibidem, s. B4.
} 
Najdzielniejszą Judytą Wojującą nazywa autor Cudowną Matkę, wyliczając jej zasługi w nakłanianiu do wiary katolickiej pogan i Żydów z taką moca, że bramy piekielne jej nie pokonają. Skoro zatem „bramy piekielne twojej o Matko Przenajświętsza siły przemóc nie mogą"39, to jakże król szwedzki mógłby to uczynić? Wspominając ogólnie czasy obrony Jasnej Góry w roku 1655, kiedy generał Müller zamierzał zająć i zniszczyć gród jasnogórski oraz opróżnić skarbiec, w pokornym dziękczynieniu zanosi wołanie, że na nic się zdała akcja dyplomatyczna i militarna generała, a także żądania poddania się, zastraszające groźby i nęcące obietnice oraz wymowne poselstwa. Agresor musiał opuścić jasnogórskie wzgórze po czterdziestu dniach oblężenia. To Najświętsza Panna poniżyła wyniosłych, a pokornym udzieliła łaski.

Inna modlitewna aluzja z dziejów cudownego obrazu dotyczy pierwszej jego koronacji 8 września 1717 roku koronami ofiarowanymi przez papieża Klemensa XI. Tytuł królewski, a także uznanie i szacunek, zdaniem autora, należą się Królowej ludzkich serc za jej dobroć i „słodkie nad ludźmi panowanie" ${ }^{\prime 4}$. To właśnie dobroć Najświętszej Matki sprawiła, że Stolica Apostolska postanowiła koronować jej cudowny wizerunek, aby mogła ona odbierać należną jej cześć, być kochaną i wielbioną jako prawdziwa, cudowna i przedziwna Matka wszystkich ludzi.

O. Rotter podaje powody, dla których wierni powinni nawiedzać wizerunek cudownej Matki. Twierdzi, że Maryja w jasnogórskim obrazie ukazuje nie tylko swój majestat, ale przede wszystkim wręcz niewiarygodną łaskawość i miłość. Jej osoba łączy dobroć i moc, które sprawiają że wszystkich podążających do Niej z ufnością obdarza niezliczoną ilością darów i uzdrowień. Nie ma bowiem takiego człowieka, który nie potrzebowałby pomocy, który nie chciałby uniknąć złego losu i nieszczęśliwych wypadków, który nie dźwiga na swoich barkach żadnego krzyża i wolny jest od utrapień. Niektórym jednak wydawać się może, że nigdy nie dosięgnie ich ani bieda, ani zmartwienia, i ci właśnie, którzy żyją pozornie szczęśliwą chwilą obecna, zapominają o dążeniu do wiecznej szczęśliwości. Takie życie stanowi dla ludzi wielkie zagrożenie, którego nie są w stanie pokonać własnymi siłami, i dlatego potrzebują pomocy „z Góry”. Kierując się zatem słowami św. Bernarda, że do Maryi każdy może zanosić swoje prośby, a Ona każdego miłosiernie obdarzy swoją łaską i pomoca, wszyscy powinni pójść przed jasnogórski obraz Miłosiernej Matki i prosić o łaskę wiecznego zbawienia. Kto jednak, pod pretekstem tego, że Matka wszędzie słyszy wołanie swoich dzieci, nie nawiedzi tego świętego miej-

\footnotetext{
${ }^{39}$ Ibidem, s. B5.

${ }^{40}$ Ibidem, s. B8.
} 
sca, uważać musi, aby w dniu Sądu Ostatecznego nie usłyszał od Chrystusa tych oto słów: „Zaprawdę powiadam wam, iż żaden z Mężów mojej wieczerzy nie skosztuje ${ }^{\prime 41}$. Każdemu, kto zwleka z pobożną pielgrzymką na Jasną Górę, autor zadaje pytanie, czy gdyby wiedział, że u kresu tej pielgrzymki znajdzie wielki skarb, nie wybrałby się natychmiast $\mathrm{w}$ drogę. O. Rotter jest przekonany, że tak. Dlatego każdy powinien zdać sobie sprawę z tego, że również u kresu pielgrzymowania do Jasnogórskiej Matki otrzyma od Niej pocieszenie, matczyne błogosławieństwo i największy z możliwych skarbów: wieczne u Syna mieszkanie w niebie. Słowa „Prędzej Niebo i ziemia przeminą, niżeli Matka miłosierdzia odmówi komu pomocy, nabożnie i z ufnością proszącemu" ${ }^{\prime 2}$ powinny przekonać każdego, że gdy tylko o coś poprosi, zapewne to otrzyma. Swiadczą o tym również niezliczone ilości łask, których doświadczyli wierni modlący się przed cudownym wizerunkiem.

O tym, jak wielkie znaczenie dla każdego powinno mieć nawiedzenie Najświętszej Maryi Panny w obrazie jasnogórskim, świadczą historie opisane w Odrobinach stołu królewskiego ${ }^{43}$. Otóż każdy powinien odpowiednio przygotować się do nawiedzenia. Autor zaleca, aby całą przebytą na Jasną Górę drogę ofiarować pokornie Matce Przenajświętszej w modlitwie z prośbą o błogosławieństwo na trud pielgrzymki. Następnie zaleca pogodzenie się z domownikami i odmówienie modlitwy na pożegnanie przed wyruszeniem w drogę. Daje również wskazówki, o czym należy myśleć w czasie drogi i o czym rozmawiać oraz jak należy zachować się w chwili ujrzenia jasnogórskiej wieży. Zaraz po tym, jak pątnik ujrzy jasnogórskie wzgórze, powinien pozdrowić Królową i odśpiewać hymn, zaś tuż po wejściu do kaplicy, idąc za radą autora, powinien odmówić z pamięci modlitwę. Następnie wskazane jest, aby osoba nawiedzająca cudowny obraz upadła przed nim na twarz i pozdrowiła Maryję. W trakcie odmawiania modlitwy powitalnej należy na chwilę przerwać ją podnieść oczy ku Matce i przyjąć jej serdeczne matczyne powitanie, po czym - kontynuować pozdrowienie. Po zakończeniu powitania autor proponuje odśpiewanie przed jasnogórskim ołtarzem hymnu zatytułowanego Do Góry Swiętej spieszne czyniem kroki albo innego, na przykład Chwałę ci daję Panno nad Panami.

Pielgrzymka na Jasną Górę wtedy tylko będzie prawdziwym nawiedzeniem cudownego obrazu, gdy pielgrzym odprawi spowiedź świętą i przystąpi do komunii świętej. Autor proponuje własną modlitwę uwiel-

\footnotetext{
${ }^{41}$ Ibidem, s. C2.

${ }^{42}$ Ibidem, s. C4.

${ }^{43}$ Por. Odrobiny stołu królewskiego, Kraków 1683.
} 
bienia Matki Jezusa Chrystusa za ofiarowanie światu Słońca Sprawiedliwości, które rozproszyło mroki ciemności i śmierci. Po przyjęciu Ciała i Krwi Chrystusa należy pobożnie odmówić "gorące supliki" do Matki Jasnogórskiej oraz modlitwę z poddaniem się pod jej protekcję i całkowite jej zawierzenie. Autor proponuje na tę okoliczność wiele modlitw i westchnień do Matki Jasnogórskiej jako Pocieszycielki Utrapionych, Ucieczki Grzeszników, Królowej Nieba i Ziemi.

Omawiany modlitewnik zawiera również wiele modlitw odmawianych w celu uproszenia u Matki Najświętszej różnych darów nieba: łaski zbawienia duszy, zdrowia, „obrony od ciężkich na sławie i fortunie przypadków", pomyślnego rozwiązania problemów oraz uwolnienia z rąk nieprzyjaciół. Autor zaleca pielgrzymom odmówienie modlitw pocieszających do Najświętszej Panny z prośbą nade wszystko o to, aby Najsłodsza pełna łaski Maryja pocieszyła w smutku, aby wybłagała u Syna Swego odpuszczenie grzechów i wyjednała poprawę sytuacji życiowej, a po śmierci żeby była przewodniczką do bram życia wiecznego.

Różnorakie modlitwy skierowane są do Najświętszej Panny, aby przybyła do umierającego w chwili jego śmierci ze słowami: „Ty jesteś synem moim, bądźże i współdziedzicem chwały mojej"44.

Na zakończenie pielgrzymki i nawiedzenia świętego miejsca autor proponuje odmówienie 15-zwrotkowego wiersza, który jest swoistym dialogiem Maryi z pątnikiem. Pożegnanie natomiast składa się z kilku zawołań „O Maryja", które są prośbami pielgrzyma o dobrą modlitwę, o zaspokojenie wszystkich doczesnych potrzeb, o godne życie i o błogosławieństwo na drogę powrotną do domu. Pątnikom wracającym z tego świętego miejsca zaleca się ucałowanie świętej jasnogórskiej ziemi, a także zabranie na pamiątkę z Jasnej Góry nie tylko wody ze studni przy kościele św. Barbary, "skutecznej na różne defekty", ale również wina i oliwy, którymi obmywano cudowny obraz. Autor radzi również pielgrzymom „zabrać obrazki o ten Oryginał ocierane”, "prosić o velum lniane czyli rąbka cienkiej materii, którym się dotyka Obraz Matki Przenajświętszej” oraz „nazmiatać otrząśnionego z nóg wielu tu pokutujących i wielu łzami oblanego prochu”, który „wielkimi pocieszy skutkami przeciwko wszelkim chorób i niepomyślności przypadkom" ${ }^{45}$. Wszystkie te pamiątki zabrane z Jasnej Góry w połączeniu z wiarą i nadzieją przyniosą pocieszenie w utrapieniach, oddalą kłopoty i zmartwienia oraz będą lekarstwem przeciwko wszelkim chorobom.

\footnotetext{
${ }^{44}$ Ibidem, s. E5.

${ }^{45}$ Ibidem, s. F3v.
} 
Opuszczającym mury sanktuarium autor proponuje odśpiewać hymn, którego słowa skierowane są do Najświętszej Matki. Również w miejscu, z którego pątnik po raz ostatni przed odejściem do domu widzi jasnogórski szczyt, powinien polecić się opiece Matki Jasnogórskiej i Ją pożegnać.

Ostatnie zdania dzieła są konkluzją wypowiadaną przez błogosławione usta Najświętszej Matki. Zapewnia ona swojemu słudze, który ją nawiedził, wstawiennictwo u Syna i obietnicę wielkiego miłosierdzia. Matka Najświętsza prosi, aby nawiedził Ją ponownie i nawiedzał tak często, aż godnym będzie dostąpienia chwały oglądania Jej twarzą w twarz na niebieskim tronie i chwalenia majestatu Boga.

Modlitewnik o. Rottera, podobnie jak inne tego typu modlitewniki ${ }^{46}$, pozwala na wgląd w kształtowanie pewnego rodzaju pobożności maryjnej, związanej z jasnogórskim sanktuarium. Mimo iż formy kultu maryjnego rozwijały się, a jego motywy były coraz głębsze, nie wpłynęło to jednak na zmianę mariologii inspirującej teksty modlitw. Zalecane w modlitewniku Rottera, wspomniane już wcześniej, „pokorne supliki”, „nabożne westchnienia”, "modlitwy pocieszające", "ofiarowania pątniczej drogi”, „pozdrowienia na widok wieży jasnogórskiej”, "hymny na wchodzenie i wychodzenie z kaplicy cudownego Obrazu”, ,,sposoby uczynienia generalnej spowiedzi na tym świętym miejscu”, , ostatnie polecenia przed drogą powrotną" - są głównymi komponentami prostej, nieuczonej, bliskiej ludowi maryjności, wpisanej w tradycję kultową i w program pastoralny jasnogórskiego sanktuarium.

O. Rotter podkreślał przede wszystkim sakralność miejsca, do którego po wielu trudach podróży przychodzi pielgrzym. Określił Jasną Górę jako miejsce szczególnie wybrane przez Boga, naznaczone obecnością cudownego obrazu i tajemnicą obecności w tym znaku Matki wielmożnej w cuda: „Samego Boga opatrzność tobie Matce Swojej ulubionej i z tysiąca wybranej dostojniejsze nagotowała miejsce, nie w Opolskim Zamku wodami i źródłami oblanym dokoła, ale na jawnym i zewsząd widocznym w Częstochowie lokuje miejscu, skądbyś najjaśniejszemi dobroci łask i miłosierdzia wszystkich mogła sposobniej oświecać promieniami" ${ }^{47}$.

Bardzo wyraźnie podkreślał również tożsamość Jasnogórskiej Pani z Maryją - Matką Jezusa, "którego nosiła w żywocie”, Matką Zbawiciela, „który w oczach twoich umierał”, z Maryją „oblubienicą Ducha Świętego" $^{\prime 4}$, ukazując tym samym teologiczne podstawy kultu częstochowskiej

${ }^{46}$ Por. A. Żymicjusz, Skarbnica kościoła Jasney Gory Częstochowskiego, Kraków 1618; A. Gołdonowski, Summariusz historiey o Obrazie Panny Mariey, Kraków 1639.

${ }^{47}$ K. Rotter, op.cit., s. A6v.

${ }^{48}$ Ibidem, s. E1v-E2. 
ikony ${ }^{49}$. Prawdę o obecności Matki Bożej w jasnogórskim obrazie Rotter wpisał w teksty modlitw przez ciągłe przypominanie samego faktu, że „na tę wstąpiwszy Górę z Bracią Pustelnikami Pawła świętego raczyła stać się współmieszkanką" ${ }^{50}$, oraz przywoływanie cudownych Jej interwencji, które objawiały się w znakach niezwykłych wydarzeń dotyczących losów narodu i poszczególnych ludzi.

W świetle omawianego dzieła jasnogórski kult maryjny pozostaje przede wszystkim kultem Matki - Bogarodzicy i Matki wszystkich ludzi. W modlitwach o. Ksawery przywołuje najsubtelniejsze określenia Jej macierzyńskiej roli. Matka Boża w jasnogórskim obrazie jest „najłaskawszą”, ",najsłodszą", ,"najdobrotliwszą”, ,"nieporównaną w dobroci”, ,"litościwą", a nade wszystko "Matką wielkiego miłosierdzia”, do której przybywa się na to święte wzgórze, przed którą staje się na tym świętym miejscu i prosi o wysłuchanie: „Pod Twoją obronę uciekam się o Maryo, synowskiej pełny ufności w tym obrazie Najmiłosierniejsza Matko" ${ }^{51}$.

Kult macierzyństwa Maryi najsilniej zabarwia modlitewną wypowiedź i angażuje ludzkie uczucia. Inspirowane nim praktyki kultowe mają przede wszystkim bardzo indywidualny, osobisty charakter. Może właśnie dlatego tak wiele w jasnogórskim modlitewniku o. Rottera próśb, zawierzeń spraw osobistych, serdecznego żalu za winy, a tak niewiele aktów dziękczynnych.

Spotkania jasnogórskich pątników z obecną w obrazie Maryją Pośredniczką sprawiaja, że w miejscu tym nieprzerwanie trwa podwójny dia$\log$ człowieka z Matką i Matki z Synem. Z tego też względu pielgrzymom przybywającym przed obraz o. Rotter zaleca: „zawiesiwszy się w myśli nieco stań, a nie modląc się nic z wielką jakąś ufnością i afektem podnieś oczy twoje ku Matce twojej i żywą uwagą pojmuj to w sobie jakobyś od Niej słodko był witany... Tymi i tym podobnymi pobożnymi myślami zabaw się nieco $\mathrm{z}$ wielkim wewnętrznym ukontentowaniem, a po tym powróć się do zaczętego pacierza" ${ }^{52}$.

Obok tytułu Matki i Pocieszycielki mariologia jasnogórskich modlitewników podkreśla jeszcze jeden tytuł Maryi - Ucieczki Grzeszników. Szuka się u niej pomocy w trudnym niekiedy powrocie do Boga. Jednocześnie zalecane jest przygotowanie się przez sakrament pokuty do owocnego odbycia pielgrzymki oraz odbycie generalnej spowiedzi po przyjściu do in.

${ }^{49}$ S.Z. Jabłoński, Jasna Góra. Ośrodek kultu maryjnego (1864-1914), Lublin 1984, s. 123

${ }^{50}$ K. Rotter, op.cit., s. A7.

${ }^{51}$ Ibidem, s. D8.

${ }^{52}$ Ibidem, s. D1v. 
sanktuarium. Związek praktyki pokutnej z praktyką pątniczą ukierunkowuje maryjność jasnogórską chrystocentrycznie i sakramentalnie.

Bardzo żywy w kulcie jasnogórskim wątek królewskości Maryi i Jej patronatu nad narodem, tak podkreślany przez paulinów po uroczystej koronacji obrazu w 1717 roku, nie znajduje wyraźniejszego odbicia w tekstach modlitw u o. Ksawerego. Wnioskować stąd można, że ten szczególny tytuł czci Matki Bożej Jasnogórskiej nie znajdował szerszego oddźwięku w prywatnej pobożności pielgrzymów.

Niewielkie objętościowo dzieło o. Rottera, liczące zaledwie sześć arkuszy druku, jest cennym przekazem o mentalności epoki, szczególnie z uwagi na fakt, że opisano w nim, w jaki sposób w owych czasach odbywano pielgrzymki do Częstochowy. Również sam układ przewodnika jest interesujący. Jak już wspomniałam, autor rozpoczyna go krótką historią obrazu, po czym daje wytyczne odnośnie do modlitw i pieśni, które należy odmawiać i śpiewać w chwili ujrzenia na horyzoncie wieży klasztornej i przed cudownym obrazem. Dzięki Ucieczce grzeszników pielgrzymi dowiadywali się o cudownej ingerencji Maryi w czasie najazdu szwedzkiego, a cytowany tam hymn opisuje wydarzenia rozgrywające się pod murami klasztoru w listopadzie i w grudniu 1655 roku $^{53}$.

Z omawianym dziełem o. Rottera związany jest również donos na drukarnię jasnogórska, dotyczący wydania tego tekstu bez cenzury ${ }^{54}$. 8 października 1844 roku Jan Bayrlein, z pochodzenia Niemiec, skierował pismo do Komisji Rządowej Spraw Wewnętrznych i Duchownych Oświecenia i Skarbu, w którym oskarżał o. Jana Chryzostoma Szusterskiego oraz generała zakonu o. Filipa Lipińskiego o to, że pierwszy z nich przetłumaczył z języka polskiego na niemiecki książkę dawniej zakazaną i zlecił jej wydrukowanie na Śląsku Pruskim, po czym sprzedawał jako wydrukowaną w drukarni jasnogórskiej ${ }^{55}$. We wszczętym śledztwie paulini wytłumaczyli, że o. Szusterski chciał puścić w obieg niemiecką wersję Ucieczki grzeszników o. Rottera, której cały nakład został już wyprzedany. Uzyskał wówczas zgodę cenzury warszawskiej i w roku 1843 kazał ją wydrukować za granicą bez pozwolenia i wiedzy swoich przełożonych. Za ten „niecny czyn” o. Szusterski został pociągnięty do odpowiedzialności, a 990 niesprzedanych egzemplarzy zostało zdeponowanych u o. Lipińskiego. Komisja Spraw Wewnętrznych i Duchownych wraz z Zarządem Okręgu Naukowego Warszawskiego dopatrzyła się w książce czterech drażliwych

${ }^{53}$ Por. H. Czerwień, Drukarnia Paulinów w Częstochowie w latach 1730-1863, Bytom 1998, s. 84 .

${ }^{54}$ Ibidem, s. 59-60.

${ }^{55}$ AJG 382, s. 77-80. 
ustępów, które na wniosek Komitetu Cenzury należało zmienić i dopiero po wprowadzeniu stosownych poprawek dopuścić do sprzedaży ${ }^{56}$. Do sprawy tej powrócił w 1856 roku prezydent Częstochowy, żądając wyjaśnienia od przełożonego konwentu jasnogórskiego, gdzie znajdują się egzemplarze książki i czy wprowadzono w nich zalecane przez cenzurę $z_{\text {zmiany }}{ }^{57}$. Nieznana jest odpowiedź klasztoru na pismo prezydenta, niemniej jednak interesujący jest sam fakt, że po dziecięciu latach powrócono do tej sprawy.

Modlitewnik o. Rottera nie odbiegał formą ani też układem treści od wspomnianych już książeczek Gołdonowskiego i Żymicjusza. W podobnym i aktualnym schemacie, jaki stosowano w XVIII-wiecznym jasnogórskim piśmiennictwie dewocyjnym, dostarczał pielgrzymom informacji o miejscu, do którego przybyli, oraz pouczał o sposobie odbywania pątniczej drogi. Przede wszystkim jednak przekazywał, tak charakterystyczny dla tego rodzaju piśmiennictwa, zestaw modlitw i wskazówek praktycznych.

Zasięg recepcji jasnogórskich książeczek pątniczych wiąże się z ich jakością oraz rozmiarem użytkowania. Niestety ustalenie liczby egzemplarzy modlitewników nabywanych przez pielgrzymów jest niemożliwe, gdyż obieg społeczny tego rodzaju piśmiennictwa w powiązaniu z trudnościami związanymi z ustaleniem wysokości nakładu poszczególnych tytułów nie podlegał żadnej obserwacji. Można jedynie przypuszczać, że oficyna jasnogórska wydawała swe druki w nakładach około 1000-2000 egzemplarzy, z uwagi na sprzyjające warunki ich kolportażu wśród pielgrzymów. Jak podaje M. Czarnowska, był to stosunkowo wysoki nakład w porównaniu $\mathrm{z}$ ustaloną $\mathrm{w}$ literaturze przeciętną liczbą 500 egzemplarzy jednego tytułu w edycjach druków XVI-XVIII wieku ${ }^{58}$.

Treści dewocyjnej książki użytkowej, drukowanej i wydawanej na Jasnej Górze, znacząco kształtowały maryjność pątnictwa jasnogórskiego. Modlitewniki jasnogórskie narzucały określony dobór lektury i kody jej odczytywania, propagowały normy postępowania, rozwoju życia religijnego i praktyk dewocyjnych, upowszechniały typy nabożeństw i formy pobożności maryjnej. Jasnogórskie piśmiennictwo dewocyjne oddziaływało na kształtowanie się wrażliwości estetycznej w stosunku do książki jako nośnika treści intelektualnych, kulturowych i religijnych. Zapotrzebowanie na tego typu pozycje było tak znaczne, że niektóre modlitewniki

${ }^{56}$ Ibidem, s. 87-89.

${ }^{57}$ Ibidem, s. 113.

${ }^{58}$ M. Czarnowska, Ilościowy rozwój polskiego ruchu wydawniczego 1501-1965, Warszawa 1967, s. 58. 
wydawano kilkukrotnie, o czym świadczy dzieło o. Ksawerego Rottera, którego jednorazowy nakład sięgał kilku tysięcy egzemplarzy. Przez dostarczanie różnego typu modlitewników Jasna Góra w znacznym stopniu tworzyła i utrwalała różne formy nabożeństw, kształtując pojęcia oraz mentalność religijną szerokich rzesz wiernych. W tym należy upatrywać istotnego znaczenia drukarni jasnogórskiej i jej wydawnictw.

Oddziaływanie klasztoru jasnogórskiego przez wydawane w oficynie paulińskiej książki dewocyjne miało szerszy zasięg. Treści wygłaszane i propagowane przez zakonników jasnogórskich w kazaniach, modlitewnikach i podczas pracy w konfesjonale były przekazywane większemu gronu odbiorców w książkach, opracowywanych i wydawanych przez paulinów oraz tłoczonych przez prasy jasnogórskie.

\title{
DAGMARA BUBEL
}

\section{Jasna Góra devotional writings of the $17^{\text {th }}-18^{\text {th }}$ centuries. The reception of the prayer book written by Ksawery Augustyn Rotter: Ucieczka grzeszników albo nabożny zasmuconych rekurs do dzielney cudami Częstochowskiey Matki}

\begin{abstract}
Aвstract. Jasna Góra devotional writings are inextricably linked with Jasna Góra Monastery as a the center of pilgrimage and the cult of the miraculous picture of Our Lady of Częstochowa. As early as the seventeenth century Jasna Góra had formed, besides its religious and pastoral significance, a thriving center for impressive written culture influencing the population through devotional utilitarian literature produced in the monastery. The very nature of these books was dictated primarily by particular needs of Jasna Góra as a hub for pilgrimage. Jasna Góra drew crowds of pilgrims, venerating the painting of Our Lady, not only from the territories of the Polish Commonwealth but also from Silesia, Moravia and Hungary. The Pauline Fathers (of the Order of St. Paul the First Hermit) were very much involved in this mass pilgrimage movement. They reached for and appealed to pilgrims through printed word in the form of prayer books that also propagated literary images of saints. The life of Jasna Góra as a holy place, the biggest pilgrimage center in Poland, was reflected in the writings produced here in the seventeenth and the eighteenth centuries.
\end{abstract}

KeY words: Jasna Góra writings, utilitarian devotional book, Ksawery Rotter, Jasna Góra Monastery, writing monks of the Pauline Order, prayer books. 